\title{
Evidence of Climate Change Impacts on Agriculture and Food Security in Nigeria
}

\author{
Bello O. B. ${ }^{1, *}$, Ganiyu O. T. ${ }^{1}$, Wahab M. K. A. ${ }^{1}$, Afolabi M. S. ${ }^{2}$, Oluleye F. ${ }^{3}$, Ig S. A. ${ }^{4}$, Mahmud J. ${ }^{5}$, \\ Azeez M. A. ${ }^{6}$, Abdulmaliq S. Y. ${ }^{7}$ \\ ${ }^{1}$ Department of Biological Sciences, Fountain University, Osogbo, Osun State, Nigeria \\ ${ }^{2}$ Department of Crop Science, Landmark University, Omuaran, Kwara State, Nigeria \\ ${ }^{3}$ Kwara State University, Malete, Ilorin, Kwara State, Nigeria \\ ${ }^{4}$ Department of Agronomy, University of Ilorin, Ilorin, Nigeria \\ ${ }^{5}$ Lower Niger River Basin, Ilorin, Kwara State, Nigeria \\ ${ }^{6}$ Department of Plant Biology, Ladoke Akintola University of Technology, Ogbomoso, Nigeria \\ ${ }^{7}$ Department of Agronomy, Ibrahim Badamasi Babangida University, Lapai, Niger State, Nigeria
}

\begin{abstract}
Change in climate and consequent global warming are posing threats to food security in many developing nations including Nigeria because of the climate-dependent nature of agricultural systems and lack of coping capabilities. The spatiotemporal pattern of temperature and rainfall of Nigeria between 1901 and 2005 (105 years), using temperature and rainfall data to support the concept of regional climate change and its impact on Agriculture and food security was investigated. Also assessed was the level of agriculture funding and output in Nigeria. Mean annual air temperature and rainfall data between 1901- 2005 (105 years) were obtained from Food and Agricultural Organization publications, National Bureau of Statistics, Central Bank of Nigeria bulletin and National Meteorological Agency. Descriptive statistics were used to analyze the data. The results showed that within the period of 105 years, rainfall decreased by $81 \mathrm{~mm}$ with increasing temperature of $1.1^{\circ} \mathrm{C}$. The unpredictability of rainfall and steadily increasing air temperature were observed from 1971-2005. The total federal budget between 2001 and 2005 averaged 824 billion Naira per year of which very small amount (14.7 billion (1.8\%)) went to agricultural sector. The actual spending was 681 billion Naira per year with 11.4 billion Naira for agriculture. Over 25 years, there were low and dramatic walloping of public spending in agriculture relative to large size and importance of agricultural sector in the economy. There is a continuous rise in output from 1987 to 2000 before it dropped in 2001. Land degradation, desert encroachment, drying up of surface waters, coastal inundations, and shift in cultivated crops over time affected the food security in Nigeria. The current available data showed that Nigeria, like most parts of the world is experiencing the basic features of climate change. Therefore, Nigerian government/ private sector partnership should encourage agricultural, industrial and domestic practices which will not contribute to the emission of greenhouse gasses.
\end{abstract}

Keywords Agricultural Production, Food Security, Climate Change, Rainfall, Temperature, Nigeria

\section{Introduction}

Climate change is one of the environmental life- threatening to economic development and sustainability of mankind worldwide. Natural climate cycle and human activities have contributed to an increase in the accumulation of heat-trapping "greenhouse" gases in the atmosphere thereby contributing to increase in temperature in the global climate (global warming) (UNFCCC, 2007). Global warming causes unpredictable and extreme weather events impact and increasingly affect crop growth, availability of soil water, forest fires, soil erosion, droughts, floods, sea level rises with

* Corresponding author:

obbello2002@yahoo.com (Bello, O. B.)

Published online at http://journal.sapub.org/ijaf

Copyright (C) 2012 Scientific \& Academic Publishing. All Rights Reserved prevalent infection of diseases and pest infestations (Ade juwon, 2004; Zoellick and Robert 2009). These environ mental problems result to low and unpredictable crop yields, which invariably make farmers more vulnerable, especially in Africa (Ziervogel et al., 2006; UNFCCC, 2007). Desertification, uncontrolled grazing, livestock migration, poaching/settlement within protected areas, bushfires and deforestation also posed threats to the environments. All these adversely affected agriculture and food supply, fresh water resources, natural ecosystems, biodiversity and human health, threatening human development and their social, political and economical survival (Zoellick and Robert 2009). The growing problem of climatic change impacts is global and the developing countries, especially Africa will be mostly affected. This is because, African economy is predominantly agrarian rain-fed, fundamentally dependent on the vagaries of weather, due to inability to cope as a result of 
poverty and low technological development, hence low level of cropping capabilities by the farmers (Ziervogel et al., 2006; Jagtap 2007; Nwafor 2007; Onyenechere 2010). It is projected that crop yield in Africa may fall by $10-20 \%$ by 2050 or even up to $50 \%$ due to climate change (Jones and Thornton, 2002).

Available evidences showed that Nigeria is already being plagued with diverse ecological problems which have been directly linked to the on-going climate change (Adefolalu, 2007; Ikhile, 2007). The southern ecological zone of Nigeria largely known for high rainfall is currently confronted by irregularity in the rainfall pattern, while Guinea savannah experiencing gradually increasing temperature. The Northern zone faces the threat of desert encroachment at a very fast rate per year occasioned by fast reduction in the amount of surface water, flora and fauna resources on land (FME, 2004; Obioha, 2008). This makes people to exploit more previously undisturbed lands leading to depletion of the forest cover and increase on sand dunes/Aeolian deposits in the Northern axis of Nigeria. On the other hand, those in coastal region are vulnerable to incessant floods, destruction of mangrove ecosystems, contamination of water and transmission of water borne diseases, leading to displacement and communal crisis (Odjugo, 2010). The resource poor farmers therefore faced the prospects of tragic crop failures which reduced agricultural productivity, increased hunger, poverty, malnutrition and diseases (Zoellick and Robert 2009; Obioha, 2009). Due to these environmental threats resulting to declining in crop yields, some farmers in Nigeria are abandoning farming for non-farming activities (Apata et al., 2010). Hence, concerted efforts toward tackling these menaces are necessary. The study of the effect of climate change on agricultural productivity is therefore critical, given its impact in changing livelihood patterns in the country. However, for a reasonable conclusion to be drawn on weather data, at least a century of evaluation of climate trend with clear and permanent impacts on the ecosystem is very imperative (Ayoade, 2003; Singer and Avery, 2007). On this premise, there is therefore the need to examine spatiotemporal pattern of temperature and rainfall between 1901and 2005 (105 years), using temperature and rainfall data to support the concept of regional climate change and its impact on Agriculture and food security in Nigeria.

\section{Materials and Methods}

The study area is Nigeria. Nigeria is one of the sub- Saharan African nations in the Western part of Africa, and shares land border with the Republic of Benin to the West, Chad and Cameroon to the East, Niger Republic to the North, and its coast lies on the gulf of Guinea (Wikipedia, 2009). The South is defined by its tropical rain forest climate, where annual rainfall is between 60 and 80 inches per year. The North has almost desert-like climate where rainfall is less than 20 inches per year. The rest of the country between the North and the South is savanna, with annual rainfall between
20 and 60 inches per year (Nation Master, 2009). Mean annual rainfall distribution and air temperatures from 1901 to 2005 (105 years) were obtained from 30 Nigerian Meteorological Stations and some States' Airports. Data of Federal Budget and Actual Expenditure on Agriculture, and Share of Agricultural Sector in Federal Capital Budget were sourced from the Central Bank of Nigeria (CBN) Bulletin. Report of Nigeria House Committee on Agriculture, Trend of Nigeria Agricultural output and Crop Production were collected from National Bureau of Statistics, and Food and Agricultural Organization (FAO) Publications. The time series was used to analyze the trend of rainfall and temperatures. The rainfall pattern was depicted using histogram, while trend lines were used to depict the slope of the rainfall and temperatures. The Share of Agricultural Sector in Federal Capital Budget and the Trend of Nigeria Agricultural output were depicted using the frequency distribution curve.

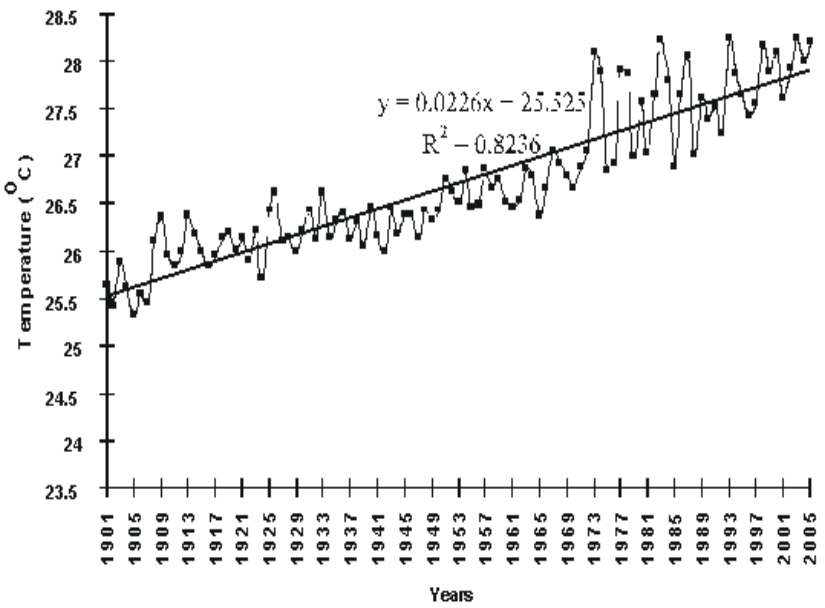

Figure 1. Air temperature distribution in Nigeria between 1901 and 2005

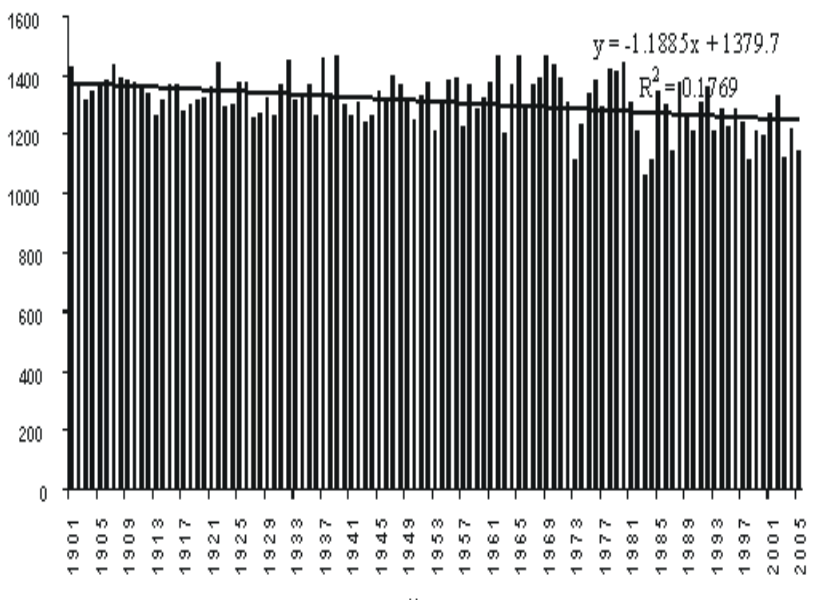

Years

Figure 2. Rainfall distribution in Nigeria between 1901 and 2005

\section{Results and Discussion}

\section{Air temperature and rainfall variation impacts in Nigeria}

In this study, the trends of air temperature and rainfall distribution in Nigerian were of temporal and spatial in 
variations as from 1901 to 2005 (Fig. 1 and 2). There is a gradual rise in air temperature between 1901 and mid 1940s with a slight drop from late 1940's to early 1950s until subsequent increase till late 1960s. However, the evidence of sudden increase in air temperature in Nigeria was observed as from the early 1970s until 2005 ((Fig. 1), This abrupt increase could be linked to the effect of climate change and its associated global warming previously reported in Nigeria by Ikhile, (2007) and supported by the global trend (IPCC, 2007). The mean air temperature from 1901-1970 was $26.3^{\circ} \mathrm{C}$ and increased to $27.8^{\circ} \mathrm{C}$ from 1971 to 2005 . This is apparently greater than the global mean temperature with the increase of $0.74^{\circ} \mathrm{C}$ since recordings commenced in 1860 (IPCC, 2007; Spore, 2008). If this trend persists, Nigeria could experience between $1.6^{\circ} \mathrm{C}$ and $4.5^{\circ} \mathrm{C}$ temperature increase risk by 2100 (Odjugo, 2010). On the other hand, there is a decline in rainfall pattern in Nigeria by $81 \mathrm{~mm}$ within the period of the study (1901-2005) with a nastiest experience as from early 1970s to date ((Fig. 2). It is worthy to note that the period of drastic rise in temperature from early 1970s corresponds with erratic and decrease in rainfall. However, computed temperature $\mathrm{R}^{2}=0.8236$ (Fig. 1 ) and rainfall $\mathrm{R}^{2}=$ 0.1769 (Fig. 2) within the period of 105 years showed significant increase in temperature in Nigeria, while non significant decrease was recorded for rainfall distribution. All these are strong evidences of climate change impact in Nigeria, because there is incessant increase in rainfall in most coastal areas and drastic decline and erratic in rainfall amount and duration in the continental interiors of the semi-arid region of Nigeria with increasing aridity (Umoh, 2007; Odjugo, 2007, 2009). Recent available evidences of climate change have been reported earlier in Nigeria by (Odjugo, 2009) who observed that the areas experiencing double rainfall maximal (Savannah) is shifting southward, while the short dry season (August Break) is being experienced more in July as against its normal occurrence in the month of August prior to the 1970s. Also, in the Northeastern Nigeria and the Niger-Delta Coastal areas, the number of rain days dropped by $53 \%$ and $14 \%$ respectively. It has been reported that the erratic rainfall pattern coupled with increasing temperature in Katsina, Maiduguri Kano, Sokoto and Nguru (semi-arid agro-ecological zones of Nigeria) could cause increase in drought evapotranspiration and desertification which resulted to decline in water tables or total dry up of some rivers and lakes especially Lake Chad with continuous extinction of forest and biodiversity (Chindo and Nyelong, 2005; Adefolalu, 2007). Consequently, persistent increase in rainfall in the coaster cities of Lagos, Calabar, Port Harcourt and Warri has resulted to floods in these cities (Ikhile 2007; Nwafor, 2007; Odjugo, 2010). With these factors, one can say with a high level of confidence that this study with other related works cited have successfully revealed that Nigeria, like most parts of the world, is experiencing the basic features of climate change. With all these anomalies, holistic approaches on climate change are required in Nigeria to stem the tide of the erratic rainfall pattern that is currently bedeviling and bothersome since 1970s.

Table 1. Federal budget and actual expenditure on Agriculture (Billion)

\begin{tabular}{ccc}
\hline Fiscal year & Budget & Actual Expenditure \\
\hline 2001 & 17,575 & 15,916 \\
2002 & 16,509 & 9,521 \\
2003 & 14,908 & 8,917 \\
2004 & 12,725 & 10,768 \\
2005 & 11,516 & 11,847 \\
Average & $1.78 \%$ & $1.67 \%$ \\
\hline
\end{tabular}

Source: Mogues et al. (2008)

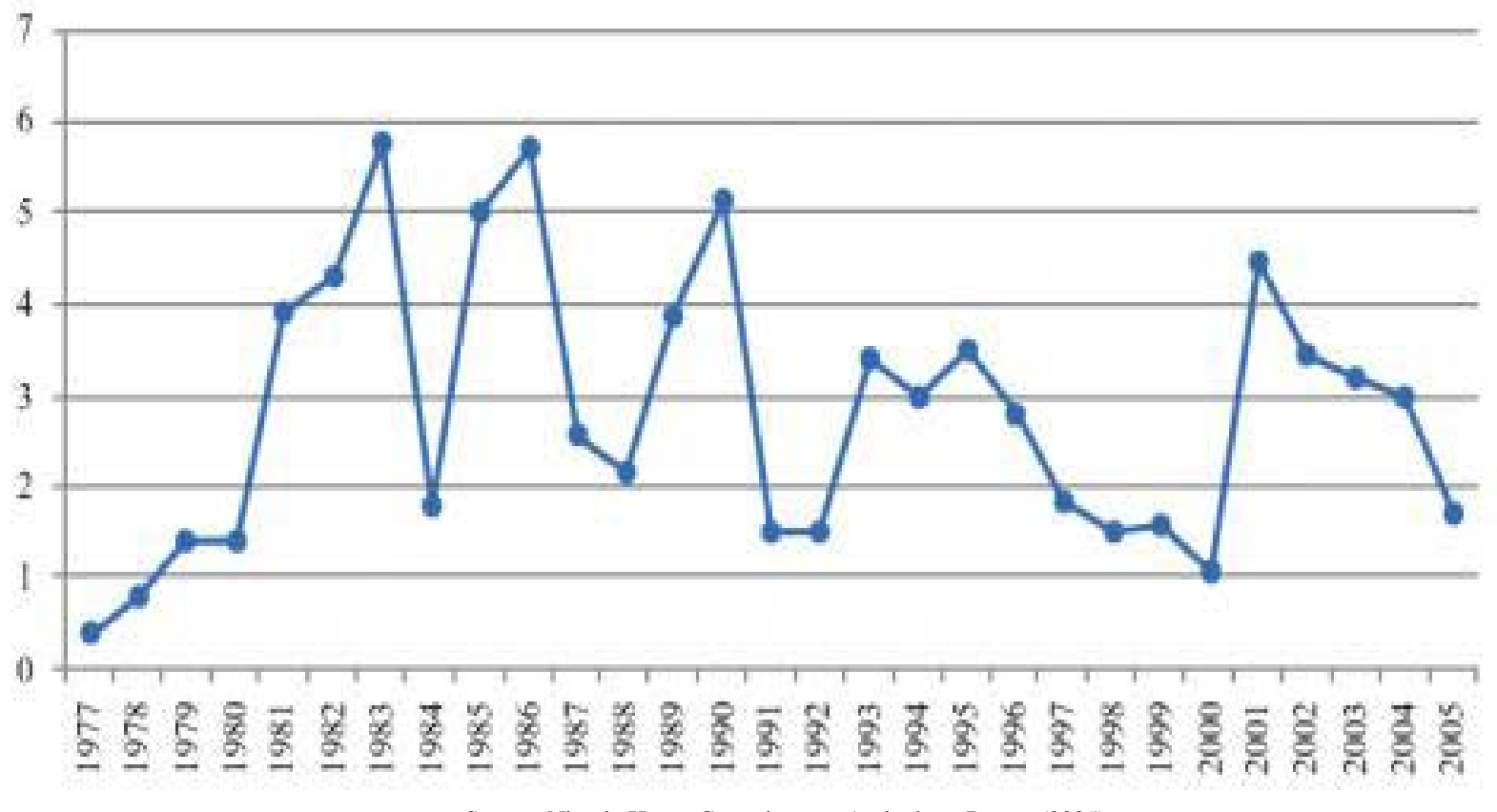

Source: Nigeria House Committee on Agriculture Report (2005)

Figure 3. Share of the Agricultural Sector in Federal Capital Budget (\%) 1977-2005 


\section{Agricultural funding for production and research}

Pragmatic assessment approach of agricultural funding relative to the size of the sector is to express public resource allocation in the agriculture as a share of agricultural Gross Domestic Product (GDP). The total federal budget between 2001 and 2005 averaged 824 billion naira per year of which very small amount (14.7 billion (1.8\%)) went to agricultural sector (Table 1). The actual spending was 681 billion naira per year with 11.4 billion naira for agriculture. Similarly, Nigeria House Committee on Agriculture between 1977 and 2005 (Fig. 3) reports revealed that agriculture share of Nigeria capital budget of about $1.5 \%$ falls short of the target set by the National Economic Empowerment and Development Strategy (NEEDS). This meager allocation to agriculture is not appropriate for a sector that is recognized as the prime driver of growth and poverty reduction in the economy. In Nigeria over 25 years, dramatic walloping of public spending in agriculture ensued relative to large size and importance of agricultural sector (Fig. 3) (Mogues et al., 2008). Mogues, et al. (2008) further noted a very low budget allocation to agriculture in Nigeria as compared to most widely cited international benchmark. Consequently, all the $\mathrm{Na}$ tional Agricultural Research Systems (NARS) were under funded as macro-economic reforms are implemented by governments. Conversely, industrialized countries have a well funded agricultural research status, private sector driven with robust linkages with the rural settings. In Mexico for example, each of the 32 States has an agricultural research station under the State Secretariat of the Agriculture Department (SEDAGRO). The research stations have more direct links with farmers at the grassroots. In Japan operates prefecture (State) level-bottom-top management system in which decisions on research and linkage activities are taken at State level without the direct involvement of national officers. In the similar vein, 13 national research institutes feed the 255 State research institutes and experiment stations through six national agricultural experiment stations. However, in some African countries particularly Tanzania, the three national research institutes are coordinated by the Division of Research and Training with substations in the 47 provinces. The Extension Programme component is managed at provincial level through Liaison Offices by the zonal directors (Agbamu, 2000). While some African countries including Ghana, Uganda and Malawi have stabilized their budget expenditures on agriculture around $10 \%$ based on the Maputo 2003 agreement, Nigeria is consistently spent less than 5\% annual budget on agriculture (Anselm et al., 2010). Malaysia has recorded tremendous achievements in agricultural development through sustained annual budget expenditure between 20 and 25\% in the last three decades (Youngstars Foundation, 2010). Conversely, the federal government of Nigeria funded and managed all the agricultural research institutes. The State and Local governments which are closer to the rural farmers are not involved in decisions on funding, direction and implementation of research activities (Agbamu, 2000). The consequence of this is low new agricultural technologies transfer to the smallholder farm families for adoption compared to developed countries. This invariably could cause serious challenges for agricultural adaptation to climate change. Current studies of Atser (2007) showed that about $8 \mathrm{~kg} / \mathrm{ha}$ fertilizer application in Nigeria is extremely below the $200 \mathrm{~kg} / \mathrm{ha}$ world average. As a result of the foregoing, this could also impede the development of new agricultural technologies such as new crop and animal varieties for climate change adaptation in Nigeria.

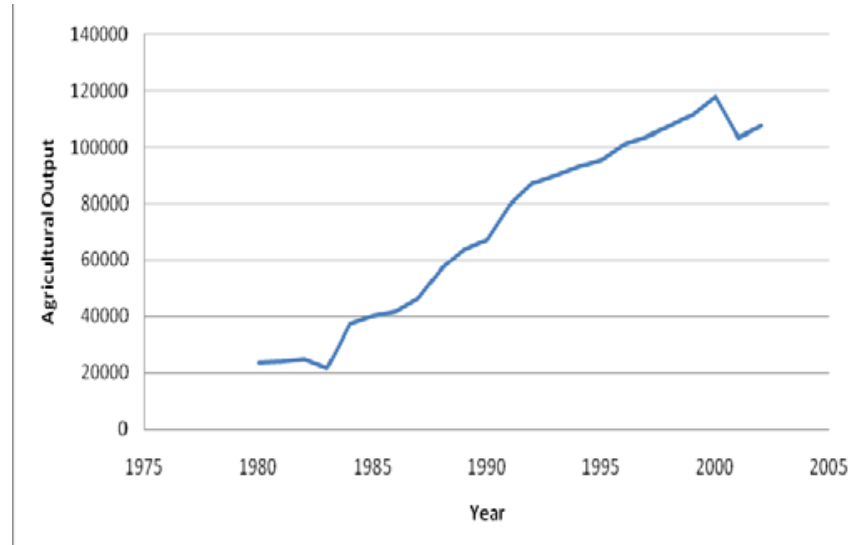

Figure 4. Trend of Nigeria Agricultural output

Table 2. Crop production in Nigeria from 2003-2005 (million tonnes)

\begin{tabular}{ccccc}
\hline Crop & 2003 & 2004 & 2005 & \% Growth \\
\hline Maize & $8,685.1$ & $9,503.4$ & $10,369.6$ & 19.4 \\
Millet & $6,561.1$ & $6,963.3$ & $7,394.7$ & 12.7 \\
Sorghum & $9,460.8$ & $9,994.4$ & $10,593.6$ & 12.0 \\
Rice (Paddy) & $3,520.3$ & $3,713.9$ & $3,929.4$ & 11.6 \\
Plantain & $1,096.0$ & $1,161.5$ & $1,246.7$ & 13.8 \\
Potato & $1,442.1$ & $1,528.3$ & $1,640.4$ & 13.7 \\
Yam & $25,073.3$ & $26,700.2$ & $28,521.8$ & 13.8 \\
Cassava & $31,698.1$ & $33,393$. & $36,057.8$ & 13.8 \\
Cocoyam & $2,350.5$ & $2,407.0$ & $2,479.2$ & 0.5 \\
Cowpea & $4,210.7$ & $4,328.3$ & $4,462.2$ & 0.6 \\
\hline
\end{tabular}

Source: National Bureau of Statistics

\section{Agricultural productivity}

In this study, the lowest agricultural production was observed in the year 1983 (Fig. 4). This can be traced to the early Pre-sap era when Nigeria experience a sharp increase in foreign earnings as a result of increased oil revenue. However, there are persistently higher rates in agricultural productivity from 1983 to 2000 . Increments observed can be likened to government policies aimed at improving agriculture in Nigeria. A sharp drop was also experienced in the year 2001, which may be due to climatic factors, changes in political views, and unrest observed in some parts of the country (Ayinde, 2010). However, from the selected crops produced between 2003 and 2005 (Table 2), plantain was the lowest crop produced in 2003, though with higher growth rate $(13.8 \%)$. Cassava production on the other hand was the highest 31, 698.1 million tonnes with highest growth rate of $13.8 \%$ to year 2005 , followed by yams, millet, maize, cowpea and rice. However, Odjugo (2009) noted climate change which led the farmers to a shift in crops cultivated in northern Nigeria. The preferred crops grown are guinea corn followed by groundnut and maize, but due to increasing 
temperature and decreasing rainfall amount and duration occasioned by climate change, the farmers as a means of adaptation in 2007 shifted to the production of millet followed by maize and beans (Odjugo, 2009). Climate change has also caused reduction of arable lands cultivation in $\mathrm{Ni}$ geria. While the sea incursion is reducing the arable land of the coastal plains, the desert encroachment with its associated sand dunes is depriving farmers of their agricultural farmlands and grazing rangelands. Moreover, the frequent droughts and lesser rains have started shortening the growing season thereby causing crops failure and food shortage. It has been shown that drought, desert encroachment and coastal inundation have started affecting the country's ecosystem leading to ecological destabilization due to climate change impact in the semi-arid region of Northern Nigeria (Odjugo and Ikhuoria, 2003; Ayuba et al., 2007). It is noteworthy that developments of agricultural technologies that are environmentally sensitive are panacea for sustainable and improved agricultural productivity in Nigeria. While new agricultural technologies that increase soil nutrient and do not contribute to change in climate should be encouraged, irrigation should also be given priority especially the drying areas in Nigeria in order to maintain stability of supplied agricultural produce.

\section{Conclusions}

Within the 105 years, there is an increase in temperature $\left(1.1^{\circ} \mathrm{C}\right)$ and decreasing rainfall amount and duration $(81 \mathrm{~mm})$ in Nigeria from 1901, but rapidly as from 1970. The air temperature patterns from 1901-1935 and 1936-1971 were almost the same, but differ significantly between 1971 and 2005. The rainfall was unpredictability and decreasing, which also differ significantly from 1971-2005. Coastal region experiencing slightly increasing rainfall since the early 1970s and August break (short-dry-season) is currently being experienced more in July as against August in the Savannah ecology. These evidences show that Nigeria, like most parts of the world, is experiencing the basic features of climate change. However, there is continuous rise in agricultural output from 1987 to 2000 before it dropped in 2001. Low budget allocation to agriculture is not appropriate for a sector that is recognized as the prime driver of growth and poverty reduction in the economy. In Nigeria over 25 years, low and dramatic walloping of public spending in agriculture ensued, relative to large size and importance of agricultural sector in the economy. There is continuous rise in output from 1987 to 2000 before it dropped in 2001. Therefore, Nigerian government/ private sector partnership should focus on improved agricultural productivity by developing technology which will not contribute to changes in climate, but increased production through proper funding and implementation. Provision of new agricultural technologies, afforestation, reduce rate of water pollution and irrigation among others will improve agricultural productivity, enhanced rate of carbon sinks and decline ozone layer deple- tion, thereby reducing the effects of climate change on humans and ecosystems.

\section{Recommendations}

\section{Effective and efficient strategies for climate change}

While natural causes of climate change cannot be stopped, the effects of climate change can either be stopped or drastically reduced by human. Clean and environment friendly technologies in both energy supply and consumption are prerequisite to reduction in emission of greenhouse gases. In Nigeria, industrial machines and automobiles should be converted to limited or no greenhouse gases emission through the use of ethanol, electric engines or solar engines. Extensive use of low cost solar energy cookers instead of wood burning devices will limit the current pressure on the Nigeria forest for firewood. Gas flaring, oil spillage in the creeks and coastal areas of Nigeria should be drastically reduced to enhance carbon sink in the coastal waters. The use of renewable energy sources such as fuel cells that convert hydrogen fuel directly into electricity without first burning it to produce heat as well as small scale photovoltaic cells should be encouraged. Terrestrial and marine ecosystems that act as carbon sinks and reservoirs to greenhouse gases should be protected and sustained by reducing bush burning and encouraging afforestation. Aluminium, iron and steel should be used for construction of buildings and household furniture in order to reduce deforestation. However, a "Clean Development Mechanisms" that will enable the developed nations to finance emission-avoiding projects in developing countries is required. This will bring credit to the industrialized nations rather than transferring non-environment friendly technologies to developing world like Nigeria. Provision of appropriate economic and regulatory framework for investors and consumers can also improve economy efficiency.

\section{Agricultural adaptation to climate change}

The private sectors and Nigeria government should drive the agricultural sector through consistent policies, holistic national adaptation strategy, proper funding and infrastructure development in order to survive the effects of climate change on humans and ecosystems. Better-equipped weather stations to prevent weather-related disasters through early warning and effective response/adaptation system should be established this will help in preventing weather-related disasters through early warning and effective response system. Establishment of disaster mitigation plans in a more formal setting and the upgrading of all systems based on advance in science and technology, with emphasis on space science will enhance knowledge in atmospheric studies for the betterment of man. The on-going plan to supply water to the disappearing Lake Chad from the Congo Basin should be intensified and brought into fruition within the shortest possible time. Transportation of water from the Atlantic Ocean to the Lake Chad through pipelines after desalination should be looked into. Such water transfer will definitely increase the 
volume and also the area coverage of the Lake. This means more water for irrigation farming, fishing, domestic and industrial usage. Readily available farming inputs (inorganic fertilizers, improve seeds and chemicals) and subsidies should be entrenched. Credit facility, extension services, effective processing and storage technologies and market systems should be provided to farmers. Education, information and training of farmers to adapt to climate change by changing their farming practices such as bush burning, deforestation, rain-fed agriculture and land tenure systems should be encouraged. Agricultural research (funding and activities) should be decentralized by making them participatory to increase adoption of innovations and encouraged increase in agricultural production. There should be integration of indigenous knowledge and practices into formal climate change mitigation and adaptation strategies. With the decreasing rainfall amount and duration, frequent drought and desertification, drought resistant and short duration high yielding crops should be developed and made available to farmers. Improved animal husbandry including improved brood stock traits, health and feeds should be provided to farmers. Encouragement of formation of farmer groups, and agricultural adaptation to climate change should be mainstreamed into government's poverty alleviation programme. Other stakeholders should invest in improved agricultural technology to be able to cope with climate change. Nigeria should start to invest on irrigation farming rather than relying more on rain-fed agriculture that is highly unreliable and becoming more unpredictable. The problems of climate change are already with us, therefore these constraints should be properly addressed for self sufficiency in food production and for export, thereby enhancing virile economy.

\section{REFERENCES}

[1] Adefolalu DOA (2007). Climate change and economic sustainability in Nigeria. Paper presented at the International conference on climate change, Nnamdi Azikiwe University, Awka 12-14 June 2007.

[2] Adejuwon SA (2004). Impacts of climate variability and climate change on crop yield in Nigeria. Paper presented at the stakeholders' workshop on assessment of impacts and adaptation to climate change (AIACC), Conference centre, Obafemi Awolowo University, Ile-Ife, pp 271-279.

[3] Agbamu JU (2000) Agricultural research-extension linkage systems: An international perspective. Agricultural Research \& Extension Network (AgREN) Network Paper No.106. pp $1-24$.

[4] Anselm AE and Taofeeq AA (2010). Challenges of agricultural adaptation to climate change in Nigeria: a Synthesis from the Literature. http://factsreports.revues.org/index678. html

[5] Apata TG, Ogunyinka A, Sanusi RA and Ogunwande S (2010). Effects of global climate change on Nigerian Agri- culture: An empirical analysis. Paper presented at the $84^{\text {th }}$ annual conference of Agricultural Economics Society held Edinburgh, Scotland, pp 345-351.

[6] Atser G (2007). Stakeholders demand scrutiny of 2007 budget. Retrieved November, 7, 2011 from http://www. budgetmonotoringng. org/

[7] Ayinde OE (2010). Empirical analysis of agricultural production and climate change: A case study of Nigeria. J. Sustain. Dev. Afri., 12(.6): 345-253.

[8] Ayoade JO (2003). Climate change. Ibadan. Vantage Publishers, pp 45-66.

[9] Ayuba HK, Maryah UM, Gwary DM (2007). Climate change impact on plant species composition in six semi-arid rangelands of Northern Nigeria. Nig. Geogr. J. 5(1): 35-42.

[10] Chindo A and Nyelong PN (2004). Lake Chad: From Megalake to Minilake. Arid Wetland Bulletin, 6: 24-27.

[11] Federal Ministry of Environment (2004). Abuja. Available at www.nigeria.com.ngcichng.org/ccinfo.php

[12] Ikhile CI (2007). "Impacts of climate variability and change on the hydrology and water resources of the Benin-Owena River Basin". Ph.D. thesis submitted to the Department of Geography and Regional Planning, University of Benin, Benin City, Nigeria, pp 234-236.

[13] IPCC (2007) Summary for Policymakers. In: Climate Change 2007: Impacts, adaptation and vulnerability. Contribution of Working Group II to the Fourth Assessment Report of the Intergovernmental Panel on Climate Change, ML, Parry OF, Canziani JP, Palutikof PJ, van der Linden E and Hanson CE., (Eds.), Cambridge University Press, Cambridge, UK, pp 7-22.

[14] Jagtap S (2007). Managing vulnerability to extreme weather and climate events: Implications for agriculture and food security in Africa. Proceedings of the International Conference on Climate Change and Economic Sustainability held at Nnamdi Azikiwe University, Enugu, Nigeria, pp 45-52.

[15] Mogues T, Morris M, Freinkman L, Adubi A, Ehui S, Nwoko C, Taiwo O, Nege C, Okonji SP and Chete L (2008). Agricultural public spending in Nigeria.International Food Policy Research Institute Discussion Paper 00789.

[16] Nation Master. (2009). Nigeria History. Retrieved from: www.nationmaster.com. Retrieved on September 6, 2009

[17] Nigeria House Committee on Agriculture (2005) Sustainable funding of agricultural sector in Nigeria. Policy Brief No. 2.

[18] Nwafor JC (2007). Global climate change: The driver of multiple causes of flood intensity in Sub-Saharan Africa. Paper presented at the International Conference on Climate Change and Economic Sustainability held at Nnamdi Azikiwe University, Enugu, Nigeria, pp 67-72.

[19] Obioha E (2008). "Climate Change, population drift and violent conflict over land resources in North Eastern Nigeria” J. Hum. Ecol., 23(4): 311-324.

[20] Odjugo PAO, Ikhuoria AI (2003). The impact of climate change and anthropogenic factors on desertification in the semi-arid region of Nigeria. Global J. Env. Sci., 2(2): 18-126.

[21] Odjugo PAO (2007). The impact of climate change on water 
resources; global and regional analysis. The Indones. J. Geogr., 39: 23-41.

[22] Odjugo, PAO (2009). Quantifying the cost of climate change impact in Nigeria: Emphasis on wind and rainstorm. J. Hum. Ecol., 28(2): 93-101.

[23] Odjugo PAO (2010). General overview of climate change impacts in Nigeria. J. Hum. Ecol., 29(1): 47-55.

[24] Onyenechere EC (2010). Climate change and spatial planning concerns in Nigeria: Remedial measures for more effective response. J. Hum. Ecol., 32 (3): 137-148.

[25] Singer SF and Avery DT (2007). Unstoppable global warming: Every 1000 years, Rowman and Littlefield Publishers Inc, New York, pp 114.

[26] Spore (2008). Climate change. Special Issue, pp 23.

[27] Umoh E (2007). Flooding problems in Rivers State. J. Environ. Sci, 4(2): 44-60.

[28] United Nations Framework Convention on Climate Change (2007). Climatic change impact, vulnerabilities and adapta- tion in developing countries UNFCCC Secretariat, Martin-Luther-King-Straat 853175 Bonn, Germany. www.un fccc.int. Jones, P.G. and Thornton, P.K. 2002. Croppers to livestock keepers: Livelihood transition to 2010 in Africa due to climate change. Global Environmental Change, World Health Organization, Geneva, Switzerland, pp 489-493.

[29] Wikipedia (2012) "Nigeria" Available online at www.en.wikipedia.org/nigeria. Retrieve on January, 62012.

[30] Youngstars Foundation. (2010). Agriculture: Nigeria’s natural and convenient soulmate. Retrieved August 7, 2010 from http://www.youngstars-foundation.org/

[31] Ziervogel G, Nyong A, Osman B, Conde C, Cortes S and Dowing $T$ (2006). Climate variability and change: implications for household food security. Assessments of impacts and adaptations to climate change (AIACC) Working Paper No. 20, January 2006. The AIACC Project Office, International START Secretariat, Washington DC, USA, pp 678-691.

[32] Zoellick S and Robert BA (2009). Climate Smart Future. The Nation Newspapers. Vintage Press Limited, Lagos, Nigeria, pp 18. 